\title{
Dva názory na blízkou budoucnost \\ (Hervé Juvin contra Gilles Lipovetsky)
}

\author{
Two opinions about the near future \\ (Hervé Juvin contra Gilles Lipovetsky)
}

\author{
Ivana Holzbachová
}

\begin{abstract}
Abstrakt
V posledním půlstoletí se stále naléhavěji ozývá otázka, zda se naše civilizace - a s ní možná i civilizace světová - nebliží svému konci. Svým způsobem na tuto otázku odpovídají i G. Lipovetsky a H. Juvin v knize Globalizovaný Západ, kterou vydali společně ve Francii v roce 2010. Zatímco Lipovetsky se snaží vybalancovat svou vizi postmoderního světa tak, aby vyústila v obraz společnosti, která nezapomíná na své (různorodé) tradice, Juvin akcentuje hrozbu globálního střetu. Oba se vyrovnávají hlavně s otázkou poměru ekonomiky a politiky a oba svým způsobem kritizují nadvládu ekonomiky nad politikou. Je přitom třeba podotknout, že jejich záběr je časově poněkud skromnější než u takových autorů jako je např. Spengler nebo Toynbee, prrípadně u těch autorů, kteři vycházejí z představy ekologické katastrofy, nicméně právě proto mohou posloužit jako materiál ke srovnání s názory svých předchưdců i současníků na společnost, která žrejmě směřuje k velkým změnám. V této souvislosti autorka jejich názory konfrontuje s myšlenkami jejich předchůdců i současníků (Feyerabend, Fukuyama, Huntington, Popper aj.) a snaží se najít shody a rozdíly.
\end{abstract}

\section{Klíčová slova}

globalizace, hyperkapitalismus, světokultura, konflikt, tradice

\begin{abstract}
In the last fifty years, we have repeatedly been confronted with the pressing question of whether our civilization, and perhaps the whole civilization, is coming to an end. G. Lipovetsky and $\mathrm{H}$. Juvin tackle this question in their own ways in the book The Globalized West, which they published together in France in 2010. While Lipovetsky attempts to provide a balanced view of the postmodern world, which results in a picture of a society that
\end{abstract}


does not abandon its (various) traditions, Juvin emphasises the threat of global confrontation. Both authors primarily deal with the question of the relationship between economics and politics and both criticize in their own ways the dominance of economics over politics. It must be mentioned that their focus is a bit narrower than that of authors such as Spengler or Toynbee, or authors building on the idea of an ecological catastrophe. However, this provides a convenient material for a comparison with their predecessors' and contemporaries' views on a society that is obviously facing great changes. The author of this paper confronts their views with the views of their predecessors and contemporaries (Feyerabend, Fukuyama, Huntington, Popper, etc.) and attempts to find similarities and differences.

\section{Keywords}

globalization, hyper-capitalism, world-culture, conflict, tradition

Snad od doby, kdy si lidé uvědomili plynutí historického času, a ještě více od momentu, kdy zvítězily teorie jeho lineárního pohybu, jsme se ptali, co nám chystá budoucnost. A to at ve smyslu náboženském, nebo sekulárním. Soustředíme-li se na ten druhý, pak můžeme konstatovat, že přibližně od konce osmnáctého století, přes století devatenácté až velmi přibližně do poloviny dvacátého, převažovaly optimistické názory. Později, s reflexí potíží, které přinášela průmyslová civilizace, růst obyvatelstva na Zemi, vyčerpávání přírodních zdrojů a změny ve světové mocenské hře, se objevovalo stále více pesimistických názorů, které může reprezentovat třeba O. Spengler, A. Toynbee, J. A. Tainter, C. Ponting a u nás např. M. Bárta a V. Cílek. V těchto dílech se často vyskytuje i aspekt - dejme tomu - morální, tj. poukaz na současné plýtvání a neodpovědný způsob života.

Vznik a rozvoj tohoto způsobu života zkoumá ve svých knihách mj. Gilles Lipovetsky. ${ }^{1}$ Během doby si Lipovetsky všímá stále více některých nežádoucích jevů, které se v moderní společnosti objevují, vysvětluje je a vyvažuje klady a přemýšlí o jejich dalším vývoji. Nicméně se dá říci, že podíl toho, co nepovažoval za správné, se v jeho knihách postupně zvyšuje. Do jisté míry to souvisí i s tím, jak se do Lipovetského zorného úhlu dostává globalizace

1 Pro ilustraci uvádím jen ty knihy, které byly vydány v češtině, a to v chronologickém pořadí tak, že první letopočet udává rok vydání ve Francii, druhý letopočet rok vydání českého překladu: Éra prázdnoty (1983/1998), Říše pomíivosti (1987/2002), Soumrak povinnosti (1992/1999), Třeti žena (1997/2000), Věčný přepych (2003/2005), Hypermoderni doba (2004/2007) a Paradoxni štěstí (2006/2007). 
a její problémy. Na některé z nich naráží i ve své knize o hyperkonzumu, ${ }^{2}$ ale především v knize Globalizovaný Západ, ${ }^{3}$ kterou napsal s Hervé Juvinem, ${ }^{4}$ jenž se v této knize projevil jako ostrý kritik Lipovetského umírněného optimismu týkajícího se západní společnosti. Právě názory těchto dvou myslitelů bych se chtěla ve své stati zabývat jako příkladem rozdílných př́istupů k faktu ohrožení naší civilizace. Přitom je nutno předeslat, že ono ohrožení cítí oba, nicméně jejich vize budoucnosti se liší. Toho si všimli i někteř́i čeští čtenáři, kteří se této knize věnovali, jako např. Jan Lukavec ${ }^{5}$ nebo Ondřej Hudeček. ${ }^{6}$ Oba kritizují Juvina jako konzervativce a pesimistu a souhlasí se spíše optimističtějším Lipovetskym.

V knize o globalizaci Lipovetsky konstatuje, že v současném světě se odehrává mnoho polemik, které vedou ke společenským konfliktům a které mohou mít svou odezvu i v politice, kde se setkáváme se snahou vrátit se ke starším hodnotám. To je problém, o němž se zmiňuje i ve svých dřivějších knihách. Nicméně to, co zde nazývá „kulturní odvetou“, není podle jeho názoru pouhá tradicionalistická vlna, nýbrž spíše další vlna demokratizace a individualizace. $V$ hypermoderním světě podle něj není nic samozřejmé. ${ }^{7}$

Lipovetsky se vrací ke svým starším konstatováním z Paradoxního štěstí, že se zvětšuje rozdíl mezi bohatými a chudými lidmi:

Rostoucí potřeby jdou ruku v ruce s prohlubujícím se nedostatkem základního vybavení u ohromné části populace. ${ }^{8}$

2 Gilles Lipovetsky, Paradoxni štěstí (Esej o hyperkonzumni společnosti), Praha: Prostor, 2007 (Paris: Gallimard, 2006).

3 Gilles Lipovetsky - Hervé Juvin, Globalizovaný Západ (Polemika o planetární kultuře), Praha: Prostor, 2012 (Paris: Grasset, 2010).

4 Hervé Juvin (1956) je francouzský ekonom a esejista. Publikuje v mnoha francouzských listech a má za sebou desítku knih, které se zabývají ekonomickými a politickými problémy současného světa.

5 Jan Lukavec, recenze knihy, iLiteratura.cz 17. 3. 2013 [online, cit. 18. 8. 2018], dostupné z <http://www.iliteratura.cz/Clanek/31337/juvin-herve-lipovetsky-gilles-globalizovany-zapad-polemika-o->.

6 Ondřej Hudeček, Globalizace: Př́ležitost pro lidské kultury, nebo jejich zkáza?, Ekolist.cz 8. 11. 2012 [online, cit. 18. 8. 2018] dostupné z <https://ekolist.cz/cz/kultura/clanky/ globalizace-prilezitost-pro-lidske-kultury-nebo-jejich-zkaza>

7 G. Lipovetsky - H. Juvin, Globalizovaný Západ..., s. 96-97.

8 Gilles Lipovetsky, Paradoxni štěsti, Praha: Prostor 2008, s. 209. 
Domnívá se, že hyperkonzumní společnost je třeba korigovat tak, aby se zmenšovaly sociální rozdíly a sílila odpovědnost. $\mathrm{V}$ tom částečně přitakává tradicionalistické kritice, nejde však tak daleko, aby se domníval, že hyperkonzumní společnost musíme úplně zavrhnout. To by byla podle něho cesta do pekla. ${ }^{9}$ Odmítá tvrzení kritiků konzumní společnosti jako přehnaná. Podle jeho názoru je třeba uznat všechno pozitivní, co spotřební společnost přinesla, a především tvrdí, že hyperkonzumní společnost nás brání před návratem autoritářských režimů (to by byla zřejmě ona cesta do pekla), protože lidé díky vzdělání a kultuře umí kriticky myslet. Tady bych si dovolila nesouhlasit. $\mathrm{S}$ odstupem dvanácti let, v době rozpoutané hybridní války a záplavy fake news, lze pozorovat, že mnoho lidí kriticky myslet neumí, že v záplavě informací nedokáže rozlišit pravdu, polopravdu, demagogii a zlomyslnou lež. Léta vyzývání k tomu, aby byla na školách posílena výuka ke čtenářské gramotnosti, přiliš úspěchu nepřinesla. Nemůžeme si být jisti tím, čím se utěšuje Lipovetsky, totiž přesvědčením, že na obzoru hypermoderní společnosti se nerýsuje absolutní nihilismus ani „poslední člověk“. ${ }^{10}$

Stejně tak odmítá Lipovetsky některé prvky ekologické kritiky a požadavek ekologů na výchovu občansky odpovědného spotřebitele. Neodmítá je však absolutně. Konstatuje, že spotřeba energie snad vyjma Evropu po celém světě stoupá a ještě nějakou dobu stoupat bude. Ale zároveň věří v rozvoj méně predátorských způsobů výroby a spotřeby a důvěřuje rozvoji výroby elektřiny z obnovitelných zdrojů. Pak by byl možný i udržitelný rozvoj hyperkonzumní společnosti. Tvrdí, že o jakoukoli předzvěst jejího zániku se jedná tím méně, že struktura produkce a spotřeby se posouvá směrem k sektoru služeb. ${ }^{11}$ Od začátku knihy nepopírá některé negativní jevy spojené s rozvojem hyperkonzumní společnosti, nicméně tvrdí, že „epocha paradoxního štěstí si [...] žádá paradoxní řešení“. ${ }^{12}$ To je to, co naznačuje na konci knihy. Na jejím začátku je to vyjádřeno pregnantněji, i když zároveň do Lipovetského mysli vniká pochybnost. Je podle něj třeba omezit spotřebu spojenou s plýtváním a naopak zvýšit spotřebu tam, kde se vyskytuje chudoba, aby se zamezilo otevírání nůžek mezi chudými a bohatými. V konzumní společnosti je třeba nastolit rovnováhu a stále nově vymezovat spotřebu a životní styl. A to tím spíše, že - jak Lipovetsky připomíná na některých místech už v $P a$ -

9 Tamtéž, s. 381.

10 Gilles Lipovetsky, Paradoxni štěstí, s. 20-21.

11 Tamtêž, s. 372-375.

12 Tamtéż, s. 21. 
radoxnim štěstí - je zde další proces, který je pro dnešní svět charakteristický a který pro něj byl charakteristický už před deseti lety, kdy tuto knihu vydal: globalizace. Lipovetsky konstatuje, že hyperkonzumní společnost pomalu zachvacuje celý svět. Přesto se domnívá, že někdy ve vzdálené budoucnosti vyvstane nová hierarchie prospěchu a hodnot, a ptá se, zda novým cílem bude navození lepší rovnováhy a zrod štastnějšího lidstva. ${ }^{13}$

Ta slova „vzdálená budoucnost“ bych ráda zdůraznila. Protože současný stav ani Lipovetsky zdaleka nepovažuje za ideální. Konstatuje, že všude je znát kritiku komercialismu, ale po zásadní změně konzumu nikdo netouží. Jisté změny ale konstatovat lze. Zákazník je přemýšlivější, shání informace, odvolává se na vědce a odborníky.

V době, kdy lidé stále zřetelněji cítí, že ztrácejí kontrolu nad vlastní kolektivní existencí, se vyhrocují občanské a kritické postoje směřující k životnímu stylu. ${ }^{14}$

Tím, že se rozhoduje, resp. tím, že nějaké zboží odmítá, zakouší spotřebitel jistý zpơsob jak být subjektem schopným změnit dané poměry a zpochybnit je. Výsledkem by mohla být obrana celkové planetární rovnováhy, recyklovatelnost a smír mezi ekonomikou a ekologií. Konzumní svět, přelakovaný na zeleno - je to pochvala nebo povzdech?

Mezi kritiky konzumní společnosti najdeme také radikální odpůrce globalizace. Ale ani zde nenachází v jejich názorech Lipovetsky nějakou jednoznačnost. Na jedné straně se kritizuje ultraliberalismus a Mezinárodní měnový fond, ale na straně druhé je podle jeho názoru cílem MMF vtáhnout rozvojové země do hmotného blahobytu. A zase si Lipovetsky povzdechne: Ti lidé požadují globalizaci s lidskou tváří. Jenomže po ruce není žádný věrohodný model alternativní společnosti.

Konzumní svět postupuje dál a dál jako nezadržitelný osud. ${ }^{15}$

Všechny lidské tendence se upírají k ideálům štěstí a kvalitního života - ale za jejich rozšíření vděčíme podle Lipovetského výlučně komerčnímu kapitalismu.

\footnotetext{
13 Tamtéž, s. 23.

14 Tamtéż, s. 153.

15 Tamtéž, s. 156, kurzíva G. L.
} 
Co chápe Lipovetsky pod pojmem „globalizace“? Vysvětluje to hned na začátku knihy Globalizovaný Západ. Podle jeho názoru nelze globalizaci odvozovat pouze z ekonomických faktorů. Konstatuje sice, že ve druhé polovině 20 . století vznikl hyperkapitalismus, který je charakterizován existencí neomezené tržní konkurence a požadavkem okamžité návratnosti, osobními úspěchy a soukromou iniciativou, podnikatelskými ideály. Pro hyperkapitalismus je příznačný také velký úpadek autority státu. ${ }^{16}$ Došlo však také k individualizaci forem existence a životních stylů, jež se rozšiřuje do celého světa. Chceme-li tedy mluvit o globalizaci, nesmíme mít na mysli pouze hospodářskou globalizaci, nýbrž také globalizaci kulturní. Rozrůstá se tzv. kultura „třetího typu“, nadnárodní hyperkultura, pro niž Lipovetsky volí název „světokultura“. Pro světokulturu jsou podle Lipovetského zásadní zejména následující skutečnosti:

1. Revoluce ve sféře informační a komunikační technologie, vznik nadnárodních mediálních sítí. Roste kulturní sektor a ten využívá podobných postupo̊ jako jakýkoli jiný sektor tržních ekonomik.

2. Kulturní počiny hrají stále větší roli. Všechno dostává své kulturní estetické a sémiotické zabarvení. Kultura vznáší hospodářské nároky. V této souvislosti píše Lipovetsky o konci kulturních rozporů kapitalis$\mathrm{mu}$, které popisuje ve své knize D. Bell. ${ }^{17}$ Masový hédonismus funguje jako významná motivace hospodářského růstu.

3. Ve světokultuře nastupuje vláda kosmopolitní univerzality, která zatlačuje do pozadí tradiční kultury a elitní kulturu starší doby. Je pro ni charakteristická neustálá změna a hojnost.

4. Zatímco tradiční kultura vnášela do života řád a smysl, světokultura desorganizaci a nedostatek řádu. Rozbíjí všechny systémy záchytných bodů, stírá hranice mezi „my“ a „oni“ a bombarduje člověka záplavou zmatených informací. Kvưli tomu vzniká všeobecná nejistota. ${ }^{18}$ To se projevuje v diskusích o tom, co to vlastně světokultura je, nakolik lidem něco přináší, nebo naopak bere. To je problém i pro Lipovetského, takže se místy setkáváme s formulacemi, které si na první pohled odporují, nicméně jejich vyústění bychom nakonec mohli přece jen označit jako mírně optimistické.

16 G. Lipovetsky - H. Juvin, Globalizovaný Západ..., s. 61-63 (Lipovetsky).

17 Viz Daniel Bell, Kulturni rozpory kapitalismu, Praha: SLON, 2000 (anglicky 1976).

18 G. Lipovetsky - H. Juvin, Globalizovaný Západ..., s. 11-15 (Lipovetsky). 
Hlavním problémem pro něj je, zda souhlasit s Huntingtonovou tezí týkající se střetu civilizací. ${ }^{19}$ Zatímco Huntington jasně tvrdí, že planeta je na pokraji možná devastujícího střetu kultur, zejména mezi evropskou a islámskou, pro Lipovetského je pravděpodobným osudem planety její „okcidentalizace“.${ }^{20}$ Nedomnívá se, že západní hegemonie ustupuje ve prospěch různých „národních“ modelů modernity. Podle jeho názoru se globalizace ponese v duchu hlavních strukturních principů moderního západního světa, i když se mohou vyskytnout místní varianty. ${ }^{21}$ Těmi místními variantami přitom nemyslí něco, co navazuje na nějaké starší tradice, ale spíš to, co je pro postmoderní společnost podle jeho názoru charakteristické, tj. větší individualizace životních stylů uvnitř jedné a téže společnosti:

Rozdíly mezi společnostmi se stírají - avšak diferenciace osob a životních stylů uvnitř jedné a téže společnosti narůstá. ${ }^{22}$

Světokultura, ačkoli vychází zejména ze západní kultury a v tom zejména z kultury v USA, může mít mnoho verzí.

Lipovetsky nesouhlasí s myšlenkou, že započala nová moderní éra, která se svou směsicí kultur vzdaluje západní základně. Tvrdí, že okcidentalizace (ve smyslu: kapitalismus, výroba, komunikační techniky, rozvoj megapolí, podobnost architektonických i oděvních stylů) postupuje. Z toho však neplyne, že všechny kultury splynou se západními kulturními hodnotami:

Strukturní základ je sice společný, ale jeho politické, ideologické a kulturní ztvárnění nikoli. ${ }^{23}$

Podle Lipovetského přihlí̌zíme pluralitní, lépe řečeno diferencované modernitě. Proces společensko-historické transformace, pod niž spadají vědecká a technická racionalizace, funkční diferenciace, společenská autonomizace, komercializace životního stylu, individualizace atd., zůstává na celé planetě totožný. Neměli bychom tedy zaměňovat základní uspořádání civilizace

19 Viz Samuel Huntington, Střet civilizací, boj kultur a proměna světového řádu, Praha: Rybka publishers, 2001 (anglicky 1996).

20 G. Lipovetsky - H. Juvin, Globalizovaný Západ..., s. 19 (Lipovetsky).

21 Tamtéz̆, s. 20-21 (Lipovetsky).

22 Tamtéž, s. 83 (Lipovetsky).

23 Tamtéž, s. 107 (Lipovetsky). 
vycházející ze Západu s výmluvností a obrazem, které se mohou proti Západu stavět. Podle principů světokultury - racionalizace, efektivita a individualizace. A to se týká i islamizace. Lipovetsky je přesvědčen, že žádné společenství, ani žádný národ už dnes nestojí mimo dosah západní dynamiky a neubrání se rozpadu svých tradic:

Čím ostentativněji jsou místní tradice předváděny navenek, tím slabší postavení mají uvnitr. ${ }^{24}$

Shrneme-li tyto Lipovetského názory, lze říci, že vítězství Západu je vítězstvím formy. Není to nadvláda ani bělošské kultury, nýbrž formy moderní racionalizace všech národů zasahující jejich myšlení a konání:

Jsme svědky světové kosmopolitizace a rozšíření univerzalistických tendencí, které jsou základem moderní éry, jak se vyvinula ze západní civilizace. ${ }^{25}$

Tato situace však má nejeden háček. Několik z nich vystihuje sám Lipovetsky, na jiné ve své kritice narazí Hervé Juvin, s jehož názory se za chvíli seznámíme.

Háček pruni: Lipovetsky konstatuje, že některé kulturní jevy zažíváme jako světové. Z toho plyne, že „světokultura tak posiluje formy nadnárodní existence a přispívá $\mathrm{k}$ pocitu, že všichni žijeme v jediném globalizovaném světě“. ${ }^{26}$ Jenomže to samo přispívá zároveň $\mathrm{k}$ relativizaci, $\mathrm{k}$ níž vedou i další formy moderního života. Výsledkem je, že „vývoj světokultury zbavuje moci tradiční nositele kulturní legitimizace a nastoluje vládu komerční, mediální a reklamní logiky“ “. ${ }^{27}$ Lipovetsky je na rozpacích. Nezpochybňuje sice kulturní relativismus, ale zároveň tvrdí, že více pozornosti se stále dostává špičkovým dílům. Na druhou stranu ale píše:

Velké autory minulosti veřejnost nadále ctí, ale nikdo je nečte. ${ }^{28}$

24 Tamtéž, s. 111 (Lipovetsky).

25 Tamtéž, s. 112 (Lipovetsky).

26 Tamtéž, s. 18 (Lipovetsky).

27 Tamtéž, s. 57 (Lipovetsky).

28 Tamtéž, s. 79 (Lipovetsky). 
Navíc lidé poznávají díla světové kultury, ale nerozumí už vlastnímu kulturnímu a hlavně náboženskému dědictví.

Světokultura demokratizuje přístup k uměleckým dílům, ale současně lidi zbavuje opory ve vlastním kulturním dědictví. ${ }^{29}$

I sama vysoká kultura podle Lipovetského ztrácí svůj obsah a mění se v sofistikované kulturní hrátky bez osobního zaujetí a hlubších emocí. Lipovetsky se domnívá, že z těchto a dalších potíží, za něž vděčíme hypermodernímu světu, zejména ztrátě dějinné orientace, by měla lidem pomoci reformovaná škola, „která by žákům a studentům dala pevné základy a učinila je duchovně a existenciálně vnímavějšími $\mathrm{k}$ rozmanitým rozměrům života a posílila jejich sebeúctu“ “. ${ }^{30}$ Zde se už opravdu vynořuje ironická, mj. Marxova, otázka, kde najít pro takovou školu učitele, zvlášt ve světě, který učitele naopak učí neučit žáky znalostem, nýbrž „kompetencím“. Kromě toho se nabízí i srovnání s Feyerabendem, a to v Lipovetského prospěch. Feyerabend v knize Science in a Free Society ${ }^{31}$ navrhuje, aby škola dala dětem v raném věku adekvátní informaci o všech známých tradicích, aby se pak samy mohly rozhodnout, kterou budou studovat hlouběji a podle které budou žít. Tak daleko Lipovetsky nejde. Většinou předpokládá, že i vybaveni těmito znalostmi se lidé přikloní k tradici vlastní kultury. Považuje to dokonce za velmi důležité.

Háček druhý: Podle Lipovetského světokultura posvěcuje dva velké kosmopolitní myšlenkové proudy - ekologii a obranu lidských práv. (Zde se zmiňuje mj. o nárůstu nadnárodních neziskových organizací.) Jenomže - a tento háček Lipovetsky zdánlivě vidí - dochází $\mathrm{k}$ tomu, že $\mathrm{v}$ hyperkapitalistické době je pojem lidských práv zneužíván ve službě strategickým národním zájmům, tj. slouží jako záminka $\mathrm{k}$ útoku na malé země, které vyvolaly skandál v západním veřejném mínění. Ne všechny země koncept lidských práv přijaly - dokonce by se dalo konstatovat, že těch, které ho nepřijaly, je víc na všech kontinentech vyjma Ameriky, Evropy a Antarktidy.

Poměry se změnily: s rozmachem světokultury nabírá na síle i odpor k Západu a univerzalita morálního a politického rozumu je zpochybňována. ${ }^{32}$

29 Tamtéž, s. 80 (Lipovetsky).

30 Tamtéž, s. 101 (Lipovetsky).

31 Paul Feyerabend, Science in a Free Society, London, 1988, s. 27.

32 G. Lipovetsky - H. Juvin, Globalizovaný Západ..., s. 71 (Lipovetsky). 
Přesto se Lipovetsky domnívá, že úcta k lidským právům se bude dále rozšiřovat:

Musíme tedy uznat, že západní kultura je sice jednou z mnoha, nese však v sobě cosi, co ji překračuje, díky čemuž její hlavní zásady získávají univerzální platnost a šíŕí se po celém světě..$^{33}$

Ale to je podle Lipovetského jen pravděpodobnost:

Hra pokračuje a dějiny mají své zákonitosti, které nikdy nelze rozumem předvídat. $^{34}$

Jakoby tady vykukoval třeti háček. Nelze nevzpomenout na Karla Poppera a jeho Bídu historicismu: Dějiny v podstatě nemají zákony, podle nichž bychom mohli a měli budovat společnost. Nicméně se nemůžeme zbavit odpovědnosti za to, co děláme. Proto musíme postupovat opatrně a s rozumem a být připraveni uznat a pokud možno napravit své chyby. ${ }^{35}$ Podle Lipovetského dějiny mají své zákony, které nemůžeme rozumem předvídat, nicméně nějak (jak?) víme, že západní kultura nese v sobě cosi, co ji překračuje a co by mělo mít univerzální platnost. Není v tom rozpor? Domnívám se, že ano a spíše souhlasím s Popperovým hlediskem. Ovšem s vědomím, že Popperovým hlavním zájmem nebyl vývoj společnosti, nýbrž vědecké poznání a že pokud se vyslovoval i ve svém stáří ke kultuře, držel se více méně svých názorů ze čtyřicátých let, ve kterých uvažoval právě jen o západní kultuře.

\section{Juvinova kritika Lipovetského}

Stejně jako jsem se pokusila vyložit souvisle názory Lipovetského na globalizaci a její vztah ke kultuře, pokusím se nyní souvisle vyložit i názory Juvinovy. Juvin se mi jeví jako tvrdý kritik globalizované kultury (světokultury) a jako někdo, kdo se obává, že současný vývoj Západu a jeho vnucování vlastní kultury jiným zemím bude mít pro Západ samotný fatální následky. Zatímco

33 Tamtéž, s. 72 (Lipovetsky).

34 Tamtéż, s. 73-74 (Lipovetsky).

35 Karl R. Popper, Bída historicismu, Praha: Oikoymenh, 2008 (německy 1945) např. s. 8-9, 57 a 125 . 
Lipovetsky se ke světokultuře staví značně smírlivě a snaží se vidět i její kladné rysy, pro Juvina je světokultura jednoznačně zlem.

Svůj výklad Juvinových názorů začnu stručným citátem, který podle mého názoru dostatečně charakterizuje Juvinovu pozici:

Kultury jsou dnes nuceny přizpůsobit se trojici dogmat: trhu, lidských práv a individuálního zájmu. ${ }^{36}$

Tento názor rozvádí Juvin v tom, čemu říká liberální projekt. Ten obsahuje tři body:

1. Míríme $\mathrm{k}$ jednotě. To vidíme např. na cestování, které nás zavádí do stále jednotného světa unifikované architektury, hotelů a módy. Kult rozvoje se snaží zničit civilizace, které vznikaly v průběhu tisíců let. Pokud se proti tomu některá z nich postaví, patří zejména podle Američanů k silám zla.

2. Liberální projekt vede k překonání kolektivních struktur ve jménu lidských práv chápaných jako práva abstraktního individua. Světokultura v tomto smyslu je negací lidské existence a lidská práva vedou k eliminaci politiky a také ke konci dějin. Tady, ačkoli to Juvin nepíše, bychom mohli konec dějin chápat ve Fukuyamově smyslu, ale v tom smyslu, který nacházíme nejspíše na konci jeho knihy Konec dějin, kde píše také o posledním člověku. ${ }^{37}$

3. Liberální projekt znamená také tvrdou revizi skutečnosti v tom smyslu, že se vše podřizuje ekonomice. Kultura je vytlačována na okraj, je chápána pouze jako zábava. Zmizely tedy podmínky pro zrod skutečného uměleckého díla. ${ }^{38}$ To se ale netýká jenom kultury, ale také demokracie. Ta se od dob svého vzniku podstatně změnila:

Demokracie bývala revoluční; dnes se elity dovolávají demokracie, aby mohly chránit své lenošky a renty př̀ed nepř́íjemnými kverulanty. ${ }^{39}$

Proto se např. objevují snahy o omezení hlasovacího práva, snahy

36 G. Lipovetsky - H. Juvin, Globalizovaný Západ..., s. 129 (Juvin).

37 Např. Francis Fukuyama, Konec dějin a posledni člověk, Praha: Rybka publishers, 2002 (anglicky 1992), s. 317.

38 G. Lipovetsky - H. Juvin, Globalizovaný Západ..., s. 136-140 (Juvin).

39 Tamtéz̆, s. 219 (Juvin). 
donutit lid, aby se vyvíjel jinak, než by se mu chtělo. Demokracie nemůže existovat bez jasně vymezené lidské pospolitosti, která si vytváří zákony, ani bez nadřazenosti politiky nad ekonomikou. Dnes však žijeme v novém ekonomickém totalitarismu. ${ }^{40}$ Nadvláda finančních trhů demokracii ochromuje. To vede v rozvojových zemích ke konfliktům a na Západě k nezájmu o politiku. Na druhé straně se po roce 1989 demokracie velmi rozšíríila. Juvin souhlasí se Zakariou: Myšlenka demokracie nachází stále větší ohlas, ale ústavní liberalismus ne. ${ }^{41}$

To, co Juvin nejvíce vytýká světokultuře, je skutečnost, že se snaží vytvořit jakousi jednotnou, globální kulturu, která se už tím stává abstraktní. Zatímco kultura měla dávat lidem klíč k pochopení společnosti, světa a života, světokultura nás zbavuje zvědavosti, úcty a odstupu, jež jsou nutnou podmínkou porozumění. Každá kultura je podle jeho názoru tvořena implicitním prvkem - tím, co z nás tvoří na první pohled tytéž lidi a z ostatních jiné. Světokultura tento implicitní prvek zavrhuje. Nechceme nic vědět o nenávisti, žárlivosti, zášti a závisti, které mnohdy stojí na počátku největších výkonů lidstva. ${ }^{42}$ Kultury, ty konkrétní a skutečné, překonávaly lidskou situaci, protože byly s to ukázat, že existuje něco cennějšího než život jednotlivce. Současná kultura je utilitaristická a ve jménu dobra zapomíná, že dobro a zlo jsou dvě tváře života. ${ }^{43}$ Juvin to vyjadřuje i jinak: dříve existovaly kultury, dnes kultura. Kultura v singuláru v post- nebo hypermoderním pojetí je cílem Juvinovy kritiky. Dnešní kultura globalizovaného Západu je kulturou rozchodu se skutečností, narůstající abstrakcí života, ${ }^{44}$ a také proto „nám zakazuje tázat se po smyslu“. ${ }^{45}$

Globalizace přicházející ze Západu ustavuje (nebo chce ustavit) kulturu a vnucovat ji ve jménu dobra všem ostatním. Tato kultura odmítá snahu odlišovat od sebe jednotlivé kultury jako diskriminaci. Světokultura chce sjednotit lidstvo tak, že zadusí všechny ostatní kultury a jejich nárok na odlišení a výběr. Je první kulturou, která v takové míře uskutečňuje spojení moci a pe-

40 Tamtéž, s. 220 (Juvin).

41 Tamtéž, s. 215-216 (Juvin).

42 Tamtéž, s. 151-152 (Juvin).

43 Tamtéž, s. 141-142 (Juvin).

44 Tamtéż, s. 117 (Juvin).

45 Tamtéž, s. 123 (Juvin). 
něz. Ekonomika se stala nutnou podmínkou její platnosti „a kultura sama přispívá k přerodu neomezeného růstu v nezadržitelnou sebevražednou sílu“ “. ${ }^{46}$

Světokultura zasahuje dokonce i do etikety a i zde drtí každou snahu po odlišnosti. Snadno přijímané „tykání je symbolem odmítání onoho odstupu, jenž se nazýval úcta, zakazoval vměšovat se do toho, do čeho vám nic není, a dnes se mu říká nevměšování nebo zdrženlivost“. ${ }^{47}$ "Světokultura se vměšuje do všeho. Dá se říci, že je destrukcí onoho odstupu, odlišností, rozdílů, které dávaly smysl a duši každé lidské kultuře." ${ }^{88}$

Juvin píše, že nejzřetelnějším symptomem světokultury je zcela nečekaně řád. Kultura má totiž uspořádat zmatený a neuspořádaný svět. Ale co je myšleno pod oním „uspořádáním“? Juvin je přesvědčen, že je to úkol zlikvidovat minulost a pamět ve prospěch přítomnosti. Zde je asi třeba připomenout, že Lipovetsky tento rys postřehl také a ve svých (relativně řídkých) kritických poznámkách o možném vyústění hypermoderní doby a světokultury, vidí žádoucí východisko v navázání na tradice minulosti. Vrat̉me se ale k Juvinovi: Likvidace minulosti je podle něho jakýsi druh (staré známé) cenzury a zákazu myšlení prováděné novými prostředky. Naše schopnost cítit, vidět a myslet se zahltí množstvím informací (z internetu a sociálních sítí). To je v zájmu ekonomické moci a odpovědnosti (nebo neodpovědnosti? - I. H.) a ještě drtivější ekonomie a politiky neviditelného státu, které se tak mohou věnovat přeměně izolovaných jedinců přesvědčených o své vlastní svobodě v porobenou a konformní masu. ${ }^{49}$

Takto vytvořená světokultura je agresivní vưči ostatním kulturám a snaží se je pohltit. A i když Juvin - na jiném místě knihy - cituje výrok Clauda Lévi-Strausse, že barbaři jsou ti, kteří považují za barbary jiné, a dodává, že $\mathrm{v}$ tomto př́ípadě jsme tedy barbary my, ${ }^{50}$ pocituje nejistotu a strach z dalšího vývoje světa. ${ }^{51}$

Kultura (západní kultura, která by se chtěla stát světokulturou) se stává zbraní. Za posledních dvacet let se kulturní průmysl podle Juvina proměnil $\mathrm{v}$ průmysl konformity. $\mathrm{V}$ hypermoderní společnosti už nemůžete věřit ničemu, dokonce by takové chování bylo považováno přinejmenším

46 Tamtéž, s. 122 (Juvin).

47 Tamtéž, s. 128-129 (Juvin).

48 Tamtéž, s. 129 (Juvin).

49 Tamtéž, s. 161-163 (Juvin).

50 Tamtéž, s. 178 (Juvin).

51 Tamtéz̆, s. 125 (Juvin) 
za společenský poklesek. Ale nejen to. Juvin kriticky poukazuje na to, že na amerických univerzitách došlo k úpadku studia cizích jazyků a poklesl také počet překládaných knih. (Proč také, když se z angličtiny stala lingua franca současné doby, když každý vědec, ale snad už i literát, který chce proniknout na světovou scénu, píše anglicky? - I. H.) Juvin tvrdí, že v důsledku toho se všechny společnosti stahují do sebe.

Vyhlašovaná tolerance zahlušila všechny otázky a pochybnosti, výsledkem planetárního soucitu je absolutní lhostejnost. ${ }^{52}$

Z toho podle jeho názoru plyne politická impotence, morální úpadek, zhroucení civilizace i mravů. Juvin kritizuje politickou korektnost. Je to právě ona, která učinila lidi bezmocnými, když nemohou nazvat to, co vidí, pravými slovy. Svět se tak stává nejen korektní, ale také virtuální. A „světokultura nechápe, jak dlouho bude lidem trvat, aby se vrátili do skutečného světa, kde existuje odlišnost a kde bolest, hněv a násilí měly hrát roli, která jim náležela odedávna: měly by ve společnosti vést $\mathrm{k}$ obnově a novým počátkům “..$^{53}$

K tomu jen poznámku: proč by světokultura (když už ji personifikujeme) měla uvažovat o takovém návratu? Uvažovala by tím o svém konci.

Vraṫme se k Juvinovi. Ten podrobuje světokulturu obrovské kritice, která vrcholí předpovědí hrůz, jež z pokusu spojit globalizaci s kulturou, tj. s vývozem západního zpơsobu života, který podle jeho názoru v podstatě nemá s kulturou nic společného, teprve čeká. Píše, že existuje velký protiklad mezi kulturou a globalizací, podobně jako mezi darem a koupí nebo uměním a obchodem. Kultura je něco jedinečného a zvláštního, zatímco světokultura vzývá uniformitu a míšení. Ze všeho nejvíce mu to připomíná podvod, v němž obchodník může obchodovat s kulturou stejně jako s otroky, ženami, orgány nebo dětmi k adopci. A přesto to existuje. ${ }^{54}$ Kultura je podřízena diktátu užitečnosti a má se stát nástrojem čehosi jiného, co stojí pod ní nebo je př́ímo nekulturní. ${ }^{55}$

Juvin konstatuje, že svět se podstatně mění, a předpokládá, že v důsledku změn se také vrátí k tomu, co on považuje za skutečnou kulturu. Změna je dána současnými hrozbami (ekologickou krizí, přelidněním, ztrátou převahy

52 Tamtéž, s. 164 (Juvin).

53 Tamtéž, s. 166 (Juvin).

54 Tamtéž, s. 191-192 (Juvin).

55 Tamtéz̆, s. 116 (Juvin). 
Západu). V jejich důsledku se vynořuje proud nesený touhou po přežití. To povede k obratu k tzv. „politice života“, která se od liberálního projektu podstatně liší:

1. V ekonomické teorii i praxi přestane v důsledku honby za surovinami platit imperativ růstu.

2. Objeví se renesance územní svrchovanosti.

3. Dojde k úpadku víry v ekonomiku. Objeví se mravní a existenciální úzkost, která může oživit hledání společenství a identity.

4. Už nyní dochází k zápasu o moc. Hlavním motivem jednání se stane hrdost. V této souvislosti poukazuje na Rusko, Čínu, Indii a islámské země - hlavně Turecko. ${ }^{56}$

Vzniká tak možnost nových konfliktů.

Výdobytky, které jsme považovali za nezvratné, mohou opět zmizet - strženy vlnou necivilizovanosti, jež se převalí přes každou společnost, která nezná vlastní hodnoty a dějiny. ${ }^{57}$

Nadcházející války nebudou vedeny žádnou institucí a nebudou ani válkami národními nebo občanskými - ale budou o to horší. Budou střetem emocí, mínění a zášti, nikoli zájmů založených na cti a na náležitém zhodnocení situace. Toto připravila světokultura v okamžiku, kdy ze života učinila předmět smlouvy. ${ }^{58}$ Jsme první lidé, kteří na všech stranách narážejí na to, že svět je malý a příroda je vyčerpána. To nás vede ke znovuodhalení smrti a smrtelnosti. Vytváří se nový svět, v němž se vracíme $\mathrm{k}$ hmotné realitě a zjištujeme, že současného světa není dost pro všechny, zvlášt když ti všichni chtějí žít tak jako ti v Americe. Vyčerpání zdrojů povede k migraci, a to v době, kdy Západ ztratil globální iniciativu. Američtí politologové už dnes (tj. v roce 2010), píše Juvin, považují Evropu za území ovládané islámem. Zároveň musíme počítat s rostoucí ekonomickou převahou Indie a Číny. ${ }^{59}$ Ty kultury, které přežily moment překvapení, odolaly uniformizaci a vzchopily se k sebeobraně, nám připravují nebezpečné překvapení. ${ }^{60}$

56 Tamtéž, s. 173-176 (Juvin).

57 Tamtéž, s. 182 (Juvin).

58 Tamtéž, s. 182-183 (Juvin).

59 Tamtéź, s. 167-171 (Juvin).

60 Tamtéž, s. 145-146 (Juvin). 
Ačkoli věta, kterou budu nyní citovat, není poslední větou Lipovetského a Juvinovy knihy, ani poslední větou Juvinova příspěvku, můžeme ji považovat za vyvrcholení Juvinových názorů:

O kultuře mají právo mluvit jen ti, kdo jsou ochotni zabít nebo zemřít za to, aby se pařřžský chrám Notre-Dame nezměnil v parkoviště či mešitu. ${ }^{61}$

Proti Juvinovým názorům nechám nyní promluvit Lipovetského, který shrnuje Juvinovy názory a zároveň proti nim staví názory svoje. ${ }^{62}$ Lipovetsky nachází pět základních bodů, o nichž je třeba vést diskusi:

1. Podle Juvina je světokultura podvod, který jen zakrývá totální ekonomizaci světa. Naproti tomu Lipovetsky v ní vidí bezprecedentní motor společnosti, kultury a individuální transformace. Světokultura obsahuje i „negativní“ principy, které jí umožňují sebekritiku a korekci.

2. Oba se shodují, že světokultura souvisí s nastolením globální uniformity, avšak podle Lipovetského uniformizace postupuje ruku v ruce s vytvářením různorodosti.

3. Juvin se domnívá, že hypermoderní kultura připravuje rozpoutání války všech proti všem. I Lipovetsky se obává vzniku nepokojů, nicméně je nepovažuje za budoucí válku všech proti všem, nýbrž za násilí nepočetných menšin a strachu většiny. Dnes mají tyto nepokoje islámský nádech, zítra se do popředí může dostat něco jiného. Obranou proti této hrozbě by podle něj měla být vzdělávací politika, politika zaměstnanosti a boj proti extrémní nerovnosti a korupci.

4. Juvin obviňuje světokulturu z destrukce identity, autenticity, umění a literatury. Lipovetsky připouští, že něco takového existuje, tvrdí ale, že globalizovaná kultura otevírá obrovské možnosti:

Nic vlastně nemizí, vše se proměňuje, recykluje, nachází nový kontext. ${ }^{63}$

Globální kultura také zlepšuje poměry na Jihu a napomáhá vzniku světa osvobozeného od hospodářské nadvlády Západu.

61 Tamtéž, s. 153 (Juvin).

62 Tamtéz̆, s. 195-204 (Lipovetsky).

63 Tamtéž, s. 202 (Lipovetsky). 
5. Lipovetsky varuje před generalizací teze o likvidaci umění a kultury. Průměrných děl vzniká spousta, ale vznikají také vynikající umělecká díla (včetně kreativní reklamy).

Lipovetského a Juvinův spor o globalizaci je jen jedním ze sporů na totéž téma, které se objevuje už nějakou tu desítku let. Protože je spojeno se sporem o různorodost kultur, který někde může končit i tragicky, mohli bychom nalézt jisté spojnice se sporem mezi F. Fukuyamou ${ }^{64}$ a S. Huntingtonem o konec dějin. Zdá se, že v realitě zatím vítězí spíš Huntingtonův (a Juvinův) koncept. Musíme ovšem přiznat, že ani Fukuyama není jednoznačně optimistický. To je vidět na jeho díle Posledni člověk, které je v českém vydání součástí jeho Konce dějin, a také na knize Velký rozurat, v níž popisuje rozklad americké společnosti v posledních desetiletích dvacátého století. Zajímavé ovšem je, že tento otřesný popis amerických poměrů Fukuyama chápe jako krizi, po níž by mohla následovat katarze vzniku nové (lepší?) společnosti. Tento umírněný optimismus má společný s Lipovetskym. Ale spolu s Popperem se asi musíme spokojit s odpovědí, že ve společnosti a jejím vývoji není nic jistého.

doc. PhDr. Ivana Holzbachová, CSc.

Katedra filozofie, Filozofická fakulta, Masarykova univerzita Arna Nováka 1, 60200 Brno, Česká republika holzbach@phil.muni.cz

64 F. Fukuyama, Konec dějin..., ale také Francis Fukuyama, Velký rozvrat, Praha: Academia, 2006 (anglicky 1999). 
